\title{
The Truth about Sale of Antique Items in Sri Lanka: An Inquisitor Study of the Antiques Market in the Galle Fort
}

\author{
Upeksha Gamage*, Chandrasiri Chithrananda, Thushari Sandya Thilakarathna \\ Department of History and Archaeology, Faculty of Humanities \& Social Sciences, University of Ruhuna, Matara, Sri Lanka
}

Email address:

upeksha_gamage@yahoo.com(U.Gamage)

${ }^{*}$ Corresponding author

\section{To cite this article:}

Upeksha Gamage, Chandrasiri Chithrananda, Thushari Sandya Thilakarathna. The Truth about Sale of Antique Items in Sri Lanka: An Inquisitor Study of the Antiques Market in the Galle Fort. International Journal of Archaeology. Vol. 6, No. 1, 2018, pp. 1-8. doi: 10.11648/j.ija.20180601.11

Received: February 24, 2018; Accepted: March 11, 2018; Published: April 9, 2018

\begin{abstract}
According to current international charters on antiquities and cultural conventions, it has been generally accepted that such items belonging to more than hundred years old are commonly referred to as an antique. Whenever definition made of such item based on the characteristics of identical features, period, usefulness, artistry, rarity, condition, material, relationship with the human being and other features were taken as basic determines. Necessary steps have been taken to protect certain historical and cultural properties enforced under various charters. The antiquities in Sri Lanka are bought illegally by foreigners under the knowledge of persons belonging to them. Thus the important historical artifacts transported to foreign countries, no such record or evidence is available to the Sri Lankans. They gather historical items and illegally sell them constantly. In this research work, much attention was paid towards historical antique market existing in and around ancient-fortress at Galle in Sri Lanka. The reason to select Galle fort was being the center of tourism plus the widely distribute in antique market. This article has investigated on the magnitude of the sale of antiquities, legality of existing sale-procedures, categories and prices of such historical items, mostly marketed items and of their prices.
\end{abstract}

Keywords: Antiquities, Antique Market, Galle Fort, Cultural Heritage, Charters

\section{Introduction}

It can be easily identified that any item belonging to certain historical period possessing some historical value in them are considered an antiquities. Such items claim certain importance only if they were recognized chronology and the purpose of such work of art. According the ability to obtain a knowledge about identical and historical value. These are the antiquities.

During the $19^{\text {th }}$ and $20^{\text {th }}$ centuries more attention had been paid on historical works and as a result, these arose several definitions as to what means by 'antiquities'. The term 'Antiques' in English language seemed to have derived from the Latin word 'Antiquus' [Antique, n. d.]. There it has been described any historical work having a minimum of 100 years existence apt to be called as an historical item. The Oxford dictionary [2017] explain that by the term antique; it indicates some building statue or a coin which had been built or made in an ancient era and still surviving intact. Also many identical features could be witnessed from those historical items. They can be recognized by the era belonging to such item artistry, rarity, condition, usefulness, material, relationship with the human being and other features.

At the Paris conference held in 1978 on the 'cultural properties' given the definition to 'antiquities' provides a list of items agreeable to be accepted are ancient tools, potteries, inscriptions, coins, seals, ornaments, weapons and Human bodies preserved by certain methods [mummies with medicines]. This Paris charters have further taken suitable action in order to protect such cultural properties as the antiquities of human culture.

As per the section 29 of the Act no. 73 of 1988, cultural property has been categorized in following objects.

1. rare collections and specimens of fauna, flora, minerals and anatomy;

2. property relating-

[a] to history, including the history of science and 
technology, military and social history: or

[b] to the life of national leaders, thinkers, scientists and artists; or

[c] to events of national importance;

3. products of archaeological excavations or of archaeological discoveries;

4. elements of artistic or historic monuments or archaeological sites which have been dismembered;

5. antiquities more than one hundred years old, such as inscription, coins, currency notes and engraved seals;

6. objects of ethnological interest;

7. pictures, paintings and drawings produced entirely by hand;

8. original marks of statutory art and sculpture;

9. original engravings, prints and lithographs;

10.rare manuscripts, old books, documents, drawings, maps, plans and publications of special interest;

11.postage revenue and similar stamps;

12. archives;

13. articles of furniture more than one hundred years old; and

14. Old musical instruments.

Meanwhile, section 48 of no 09 of the archaeology ordinance 1940 and section 16 of no 24 of the archaeology [amended] ordinance 1998 have classified antiquity as follows.

'Antiquity' means,

[a] any ancient monument, or

[b] any of the following objects lying or being or being found in Sri Lanka,

which date or may reasonably be believed to date from a period prior to the 2nd day of March, 1815:- statues, sculptured or dressed stone and marbles of all descriptions, engravings, carvings, inscriptions, paintings, writings, and the material whereon the same appear, all specimens of ceramic, glyptic, metallurgical and textile art, coins, gems, seals, jewels, jeweler, arms, tools, ornaments, and all other objects of art which are movable property.

According to the archaeological ordinance [amended] act no 24 of 1998 has amended the section $48^{\text {th }}$ of the main charter it has been interpolated following definition in to the original definition given to the term 'Antique'

'Archaeological Heritage' means that part of the material heritage of mankind in respect of which archaeological methods provide primary information and includes all vestiges of human existence and places relating to all manifestations of human activity, abandoned structures and remains of all kinds [including subterranean and underwater sites], together with all the portable cultural material associated with them.

Now it is clear, according to the charters and the definitions, antique falling into category of cultural properties. Under such back drop, this study aims to present the current situation of the illegal aspects of the market in antiquities with examinations of the criminality of this type of market in Sri Lanka with special focusing to the antique shops operated within Galle fort.

By this study it is planned to consider on the matters like; types of historical curios, major sale items, prices of antiquities, for whom the market targeted, the status of antiquities held in these market and also about the legal atmosphere relevant to these dealing.

\section{Materials and Methods}

\subsection{Methodology of Study}

The survey was mainly focused on gathering data and information from shop owners, mobile sellers, foreigners and local people who have interests for and deals with antique items at the Galle Fort where storing, displaying and marketing of antique items are carried out. Several owners of this market provided the data and information about their businesses while some of them have refused to provide data and information. Even some of them have explained the methods of re-producing historical replicas. Concurrently, discussions were held with foreigners and obtained relevant details about antiques items which they have bought to carry back home with them. Discussions were also held with the local people who purchased these ancient items as well.

\subsection{Site Selection}

In the field study much attention paid on 'antiques market' existing in and around Galle fort. There are several reasons to choose Galle fort in this correction.

1. Galle Fortress has been declared as a world heritage site. Majority of tourists arrived to Sri Lanka chose to visit this old town. Hence the visit to Galle in multitudes.

2. City of Galle, being a natural and historical city, had been inhabited by all the Portuguese, Dutch and British communities, there by the availability of numerous and bountiful historical goods and items.

3. Since early times there flourished the antique market targeting foreign travelers, pilgrims and traders had become a developed fort city where the widespread trading stalls were much busy all the time.

4. There are many antique available in Galle fort antique market, found from many an archaeological sites in southern province and other provinces too.

5. Non-availability of similar antique markets complete with above mentioned facilities elsewhere in the island.

It has been decided to select for Galle fort in order to carry on this research work due to aforesaid favorable environment. Main point of field survey was the market that collected exhibited and sold antique within the fortress itself and also look into the activities corrected with these fraudulent businesses. 


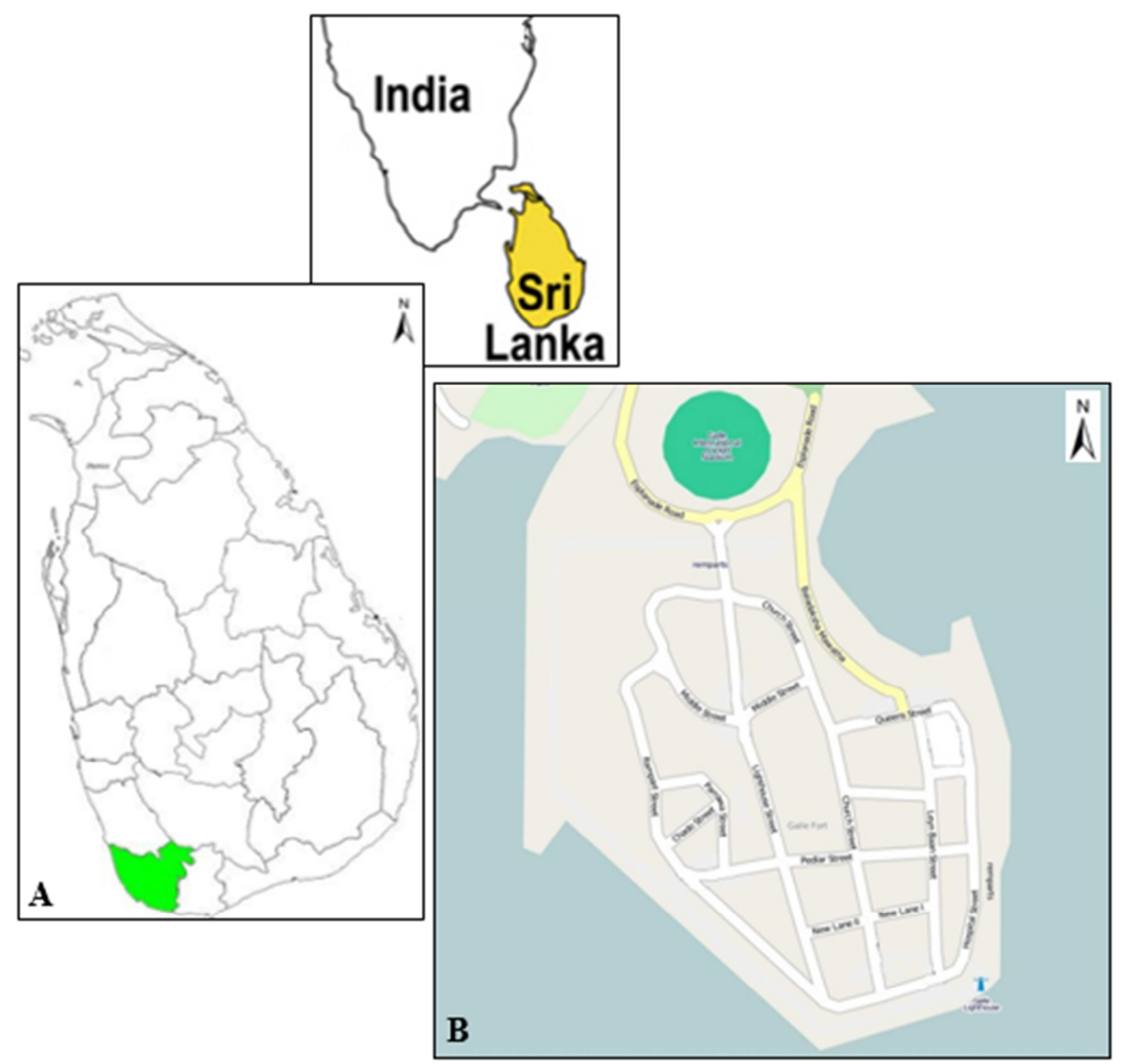

Figure 1. Study area. A: Galle Fort [Galle District, Southern Province of Sri Lank] is indicated by the star. B: Galle Fort.

\subsection{Library Survey}

In this mode of study attention paid on national and International charters and acts regarding antiquities and their market have been consulted comprehensively. Existing black markets on these ancient items too were studied through internet and websites.

\section{Results}

\subsection{Antiques Market}

Antiquities symbolize life styles of bygone eras and attract interest of any person. This very reason has built up a black market aiming only financial gains thus ignoring cultural heritage, historic importance and protection of those time honored antiquities. Here age-long antiquities are gathered indiscriminately and sold illegally.

International market for historical goods is very old and has a long history. Its highest point been the Renaissance period, during that era these flourished many disciplines of Arts, Science, Literature, Commerce. Along with the voyages of discoveries, colorizations, missionary movements, explorations and foreign travelling enabled Europeans to reach other countries of the world.

Especially during the $15^{\text {th }}$ to $17^{\text {th }}$ centuries European nations began voyages of discoveries to find out new lands and states primarily as traders. They can travelled many countries in Asian, African and American continents and plundered huge quantities of cultural, historical and artistic works which they brought down to their own countries. Thus occurred an immense accumulation of antiquities hither to own by different nations [Silva 1996]. Also during the renaissance age [14-17 centuries A. D.] in Europe many kings, lords and wealthy man maintained cabinets of curiosities [Silva 1996]. This situation helped built Victoria and Albert museum later on. Afterwards many personages who desired to collect antiquities of different lands began to 
gather such important items themselves. These competitive influences have created antique market.

Because of his natural tendency and attraction towards historical works people with means tried to collect such antiquities as possible. This fact established financial value of selling of antiquities recovered from such sites illegally by the $21^{\text {st }}$ century this antique market have spread widely over the world. As such it has become possible to sell any antiquities belong to any country to any other country. This situation has become so aggravated by this $21^{\text {st }}$ century with the advent of electronic mode of communication. By this was there available a possibility of purchasing an item of historical value belonging to another country.

It is widely accepted that since colonial times many antiques had been taken out of Sri Lanka and transferred to European countries. Antique market has been established with the sole intention of collecting and selling such national treasure in return to petty gains.

Galle fort can be identified as a major market in this regard. How this market is flourishing can be witnessed easily. This antiques market has extended to Galle town and to entire southern province too. This illegal market is visible around Bentota, Hikkaduwa, Ambalantota and Katarahgama junction. Antiquities are also secretly sold at archaeological site in Anuradhapura and Polonnaruwa. Another significant feature identified at the antique market was the high demand for colonial period coins. The other demand item is jewelry made with old beads.

Some of the antiquities sold fetched very high amounts. At times imitations are also sold to foreigners. Certain foreigners do not hesitate to purchase precious antiquities even at a high price. Some traders use to sell truly made original items at higher cost accusing other of cheating foreign buyers by producing imitations.
Some local peoples have used to gather antiquities and maintain them and display well. Local buyers are also attracted to these display shops. Still some other sell off traditional heir-looms for financial gains neglecting their true value. As a result an internationally famous antique market has been set up in Sri Lanka by this time. A widespread activities connected with "Excavating treasures" are happening around archaeological premises and ancient sites.

Basically these antique market had been set up aiming at foreign tourist. This has resulted a clean threat posed to Sri Lankan heritage being separated from this island nation who built up a glorious civilization. During the field study it was realized that this antique market was flourishing not only for foreigners but also for local buyers. Sri Lankan living in other countries, local wealthy people and also the collection of curios belong to this category. Traders said that "sometimes these items are bought for religious purposes likes depositing of relics etc. in shrines and other places". Anyhow majority of the buyers constitute with foreigners.

\subsection{Antiquities}

Foreigners used to purchase antiquities unlawfully even with the knowledge of the owners of such items. Hence the threat of departing of antiquities out of this country whence these antiquities left this land these will evidence or any remark left behind about such valuables. Multitude of collection centers called them as 'museum' and showroom are filled with clay vessels, porcelain, tusk made items, turtle shell work, old coins, jewelry, tools, weapons, Ola leaves marks, wood work, glass ware, metal work and clothing items brought down by foreigners. In addition, various parts of old buildings with artistic and archaeological importance can also be seen. Table 1 clarifies these different collections.

Table 1. Items for sale [Source: Field study - 2017].

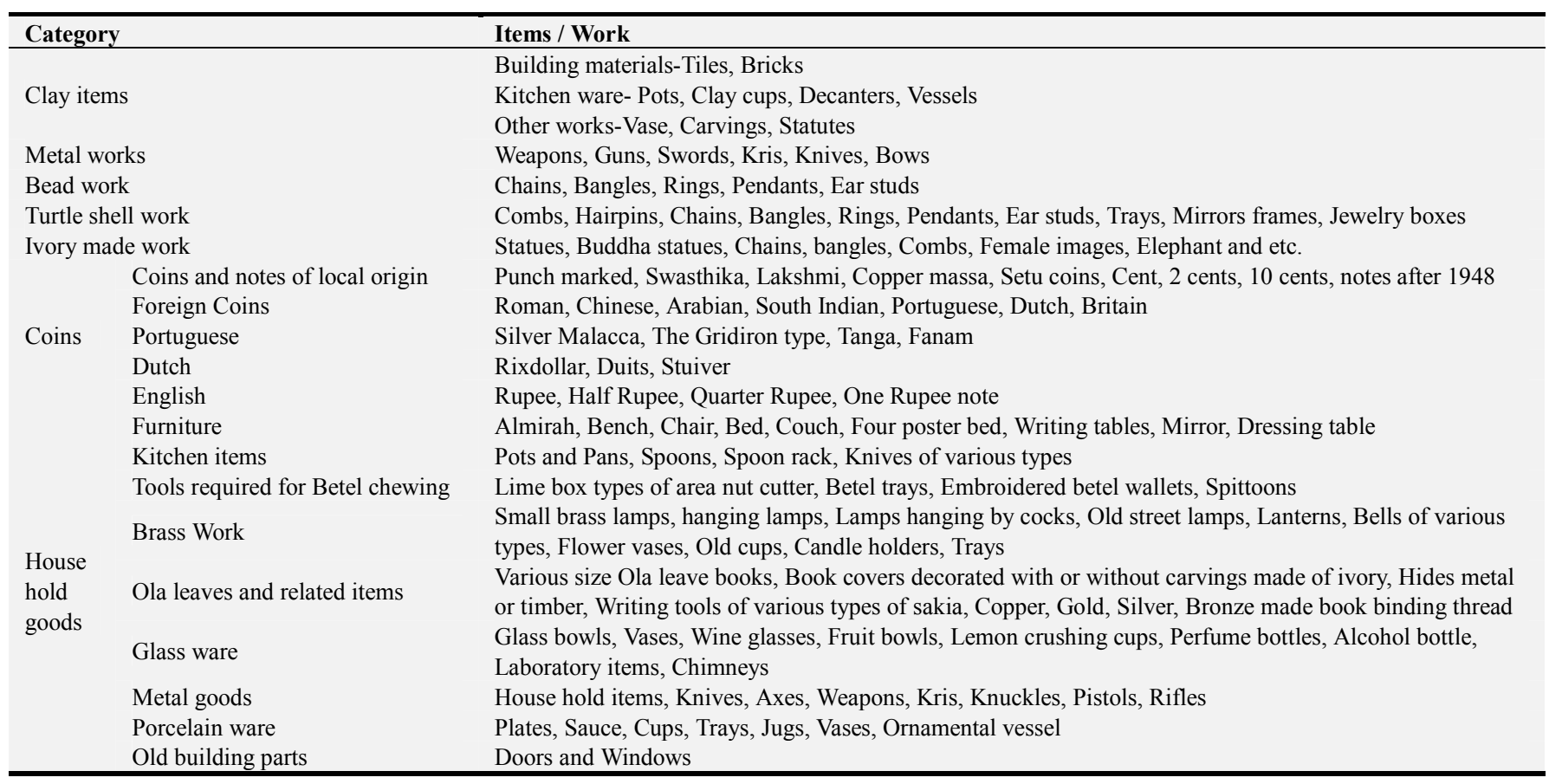


Antique market existing around Galle fort might have been fed by antiquities recovered from the excavations and explorations carried out by archaeological surveys particularly in Southern Province in Sri Lanka. Creative goods like chains, bangles, ear studs and rings made with beads and also old coins are sold in large scale. Some shops even display the selling prices of these items. These sales are carried out in so called "museums" maintained by individuals.

\subsection{Prices at the Antiques Market}

This antique market is not a genuine and lawful market system. Although these shops are being called as antique shops or museums or by another names they have not been registered as antique sale ventures. They are therefore plying their trade in public or in privacy without any legal permission. These businesses could be carried out adhering to the legal background in connection with the export rules in regard to antiques, but it can be seen these markets secretly doing their businesses in large scale.

Prices of antique items are determined according to their value in the open market. These differs the value and prices for foreign and local buyers. Prices are also determined according to the buyer's necessity, on the price he/she offers, demand of the item, its rating, artistic value, finishing, value of the material used and also its historic significance. Very high prices are demanded for the prohibited items and more ancient items and the items controlled by legal ordinances.

At our inspection made in the field study we were able to see for ourselves the prices fixed for certain antiquities. Sometimes price label were stuck to the antiques. These kind of antique were not so rare and not sure of their historical standing, but possessing some olden features. However price tags are not to be seen on the expensive antiquities which were exhibited in the display cabinet. We have observed that those prices are agreed upon with the discussion of the deal between the buyer and the seller.

It was found difficult to discover the prices on vintage coins especially coins of heavy demand. Nevertheless from the information obtained from the brokers of private antique museums and antique shops those prices can be produced. Tables 2 and 3 provide the required information.

Table 2. Prices of antiques [Source: Field study - 2017].

\begin{tabular}{ll}
\hline Types of the antiques & Fixed prices [LKR] \\
\hline Lime boxes of various sizes & $4500-15000$ \\
Bells of various sizes & $2000-4500$ \\
Brass bowls & 1200 \\
Brass knifes & 1500 \\
Keys & 2500 \\
Large size areca nut cutters & 7500 \\
Coins & \\
Lakshmi plaques & 2500 \\
Swasthika coins & 2500 \\
Coins minted during Polonnaruwa era & 1000 \\
Coins of Dambadeniya period & 1000 \\
\hline
\end{tabular}

\begin{tabular}{ll}
\hline Types of the antiques & Fixed prices [LKR] \\
\hline Roman coins & 800 \\
Dutch coins & $700-3500$ \\
British coins & $500-4500$ \\
One cent coins & 300 \\
Ceramic Ware & \\
Chinese ceramics & 3000 \\
Dutch ceramics & 3000 \\
British ceramics & 2000 \\
Gems and semi-precious gems & \\
Gems & 5000 and above \\
Semi-precious gems & $1600-16000$ \\
\hline
\end{tabular}

It came to be known that the prices of following antique items are changed upon their sizes are of manufacture, with or without carvings, raw materials used.

Table 3. Prices of antiques [Source: Field study - 2017].

\begin{tabular}{ll}
\hline Items & Prices [LKR] \\
\hline Jewelry & $1000-150000$ \\
Statues & $8000-16000$ \\
Photographs / Paintings & $600-7500$ \\
House hold goods & $2500-8000$ \\
\hline
\end{tabular}

\subsection{Legal Position}

Antique market has now been grown into an uncontrollable state. Although various national and international acts and ordinances, declarations had been enforced, conferences hold, it cannot be seen that desired implementation of required actions taking place.

When investigating about the legal position with regard to the existing law it appeared that these exists both types of legally permitted shops and also unpermitted shops operating in secrecy. Shops possessing lawful license have been permitted to buy or sell antiquities at a price in keeping with the condition and type of items. This procedure is adhered to the permission legally granted. Anyhow sales dealing unlawfully are conducted secretly. Such traders exhibit various items in their market and sell the antiques in secretly.

International rules and regulations have been enforced in regard to the selling of antiquities. In keeping with the "Cultural property charters" of pains [1970] it has been proclaimed certain matters about the transfer of cultural property out of the country unlawfully and bestowing upon another person illicit importing and exporting of such valuable.

Specifications have been issued about the selling of antique items by section-3 of this charter. It further clarifies that it is unlawful act to transfer of antiquities to another country owing due to any reason. Such an item is totally belonging to the country of its origin [1970].

According to the section- 6 of the charter these should be a permission given to sell an antiquities to any other country [1970].

In addition proposals have been agreed upon to prevent and to protect export of cultural property by Hague 
conventions [1954, 1999].

UNESCO sponsored conference held in 1976 in this connection has proclaimed that all the movable properties possessing archaeological, historical, artistic, scientific or technological values required to be preserved irrespective of whether they were made by man or nature. Accordingly rules and regulations applicable to legal background have been promulgated at various conferences with regard to the cultural properties.

Nevertheless these legal enforcements are not in operation in reality and as a result, certain problems have cropped up in different countries the world over. With regard to the laws existing already in Sri Lanka about antiques; we can see the present situation as updated and amended rules and regulations have been made to earlier rulers from time to time.

Archaeology ordinance number 09 of 1940 has been amended several times and new regulations introduced. Among these introductions which have been designed to prevent the flaw of antiques in to the antique market. One such section added was the "The government pays the market value of antiques" enabling government pays the market value of the item to the trader and take care of that valuable item. According to the government possess the authority to buy such antique. Nevertheless the black markets used to purchase those items at a higher price and they believe that they can still earn higher prices for them. These businessmen come forward to buy such worthy items at higher prices than the estimated prices as decided by the Department of Archaeology.

In addition to the Archaeological ordinance, part of section 2 of the Act no. 73 of 1988 about the cultural property mentions about the exportation information of cultural property. Accordingly a person cannot export an antique item without obtaining the required license. Further section 3 of the act make aware of the issuing of licenses for the dealing with cultural property. As per $18^{\text {th }}$ and $19^{\text {th }}$ sections licenses are issued without which a person or any other person in his name shall not keep a business to sell cultural property or to maintain a business with the purpose of selling such antiques.

Whenever the commissions general of Archaeology issuing such a license it will be taken to consideration in accordance with the section 19 of the aforesaid Act; experience to conduct a business venture for the sale of cultural property, intended town, village or area to conduct such business.

As such, any trader who wants to conduct a market for the sale of antiques shall first have to the purpose. Anyhow, it came to be known that those shop owners in and around Galle fort do not possess these licenses. Archaeological department can take legal action against such unlawful traders as per section 5 of the cultural property acts no 73 of 1988 . Commissioner of Archaeology or any other person authorized by him has the power to inspect all the antiques available for sale at any time as per the section 24 of the cultural property act no. 73 of 1988 .

Despite all the legal provisions in operation antique market in Galle exist without any legal atmosphere. Not a single market or a shop has not obtained any legal permission or registration what so even with regard to the sale of antique. Further these dealings are not subjected to any supervision or guidance by the Archaeological Department or by other legal institution. As a result numerous movable antiques of the national heritage are flowing out of the country any legal permission.

\section{Discussion}

During the field survey it was clearly realized that the antique market around the Galle fort area in Sri Lanka has been directly created targeting foreigners. It was also observed that both the local wealthy men as well as Sri Lankan persons living in foreign countries patronize these shops. These shops have not obtained any legal permission to sell antiquities. Furthermore, it can be seen that the archaeological artifacts market is a much closed arena in which transactions are carried out in open market as well as confidentially. The sales person uses their verbal competence to titivate the potential buyer's imagination. Their sales patter influences the decision to buy and the final price. This is not only an object which is being sold but also an object with a story. All the activities of collecting antique, exhibition and marketing of them are affected only by private sector while the public sector has no hand in it. It is observed that the private sector has organized in several ways in this regard namely, single owned business; business owned by several persons; business owned by a private firm or several firms; and mobile businessmen. At these businesses engaged in collection of antiques, exhibition of selected part of antiques, sale of known and unknown antiques. During the field study it became possible to discover some eleven places, i.e. Historical Mansion Museum, Dutch Gallery, Sithuvili Gallery, Oland Antiques, Sandaken, Prasanna Gems and Jewelry, Ramd Art, Galle Fort Jewelry, Galle Fort, Dutch wall Arcades, and Carousel Jewelry engaged in the collection and exhibition of antiquities. However, there may be many more places of these types within Galle fort itself. Furthermore, these are still some other places where the residents are living in the rear part of the house while the front part used to display and sale of antiques allowing only foreigners to enter in. 


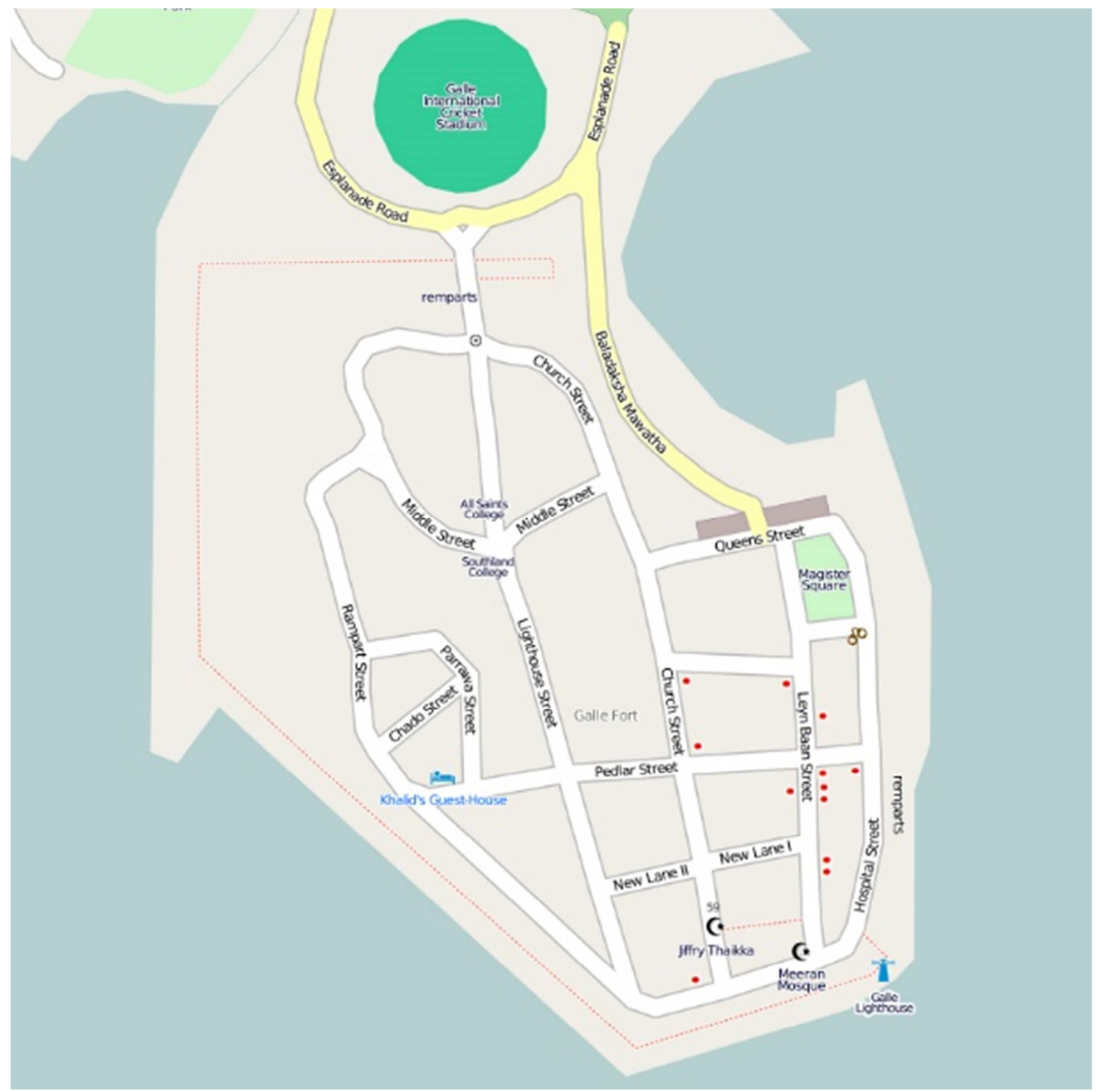

Figure 2. Study sites discussed in this paper are indicated by the dots showing antiques markets.

With the discussion held along with the brokers, it was revealed that the foreign buyers have more attraction towards old jewelry and old coins, although rare and common antiques are sold in antique shops, museums and in private houses. Currently, it can be seen that the antique markets is not limited to the Galle area. It was spread to other old cities around the country, i.e. Thissamaharama, Akurugoda, etc. Due to this heavy demand large quantities of imitated coins are being forwarded to Galle antique market, brokers revealed [Dharmasiri, 2017].

Old coins were the most demanded item of all the antiques available in Galle antique market. The reason for this heavy demand is the interest shown by the native tourists as well. Perhaps the reason for this interest may be the easiness in keeping sale and as souvenirs reminding the authority of old colonial powers. Other reasons are the educational and entertainment purposes and easiness of avoiding airport and customs regulations applicable to illegal exportation. There are no written records kept on these coins trade while the buyers and sellers carry on the trade behind the screen.

It seems that, though the rules and regulations on cultural property have been promulgated, certain practical problems have caused the difficulty of enforcement of them. As such, the antiques market runs constantly ahead of rules and regulations. Therefore it is required to formulate an effective legal framework organized as national and international enforcement with regard to the selling of antiques and cultural property. Further delays in taking suitable action 
would cause many countries disown their cultural heritage.

\section{Conclusion}

The antiquities market is characterized by a strong emotional dimension because artifacts have meaning and some are symbols of national identity. So, the present study aims to the current situation of the selling in antiquities, specifically cultural objects which are transported from Sri Lanka to other countries illegally.

The findings attested that the antiquities are sold to foreign tourists without any legal permission. Herein, the cost reckoned upon their archaeological importance, artistic value, use of valuable raw material and rarity. It does not seem any sufficient procedure enforced in a satisfactory level. There is no protection to our heritage which has become a saleable commodity in the antique market. Furthermore there has no any implementable procedure to keep records of such invaluable items flawing to the hand of foreigners.

\section{References}

[1] Act No. 09 of 1940, Archaeological Ordinance, Colombo: Government Printing.

[2] Act No. 73 of 1988, Cultural Property, Colombo: Government Printing.

[3] Act No. 24 of 1998, Antiquities [Amendment], Colombo: Government Printing.

[4] Act No. 09 of 2000, Archaeological Ordinance [Amendment], Colombo: Government Printing.

[5] Antiquities Ordinance, 1956 Revision, Colombo: Government Printing.

[6] Convention for the Protection of Cultural Property in the Event of Armed Conflict with Regulations for the Execution of the Convention 1954, Hague, 14, May 1954.
[7] Conservation on the means of Prohibiting and Preventing the Illicit Import, Export and Transfer and Ownership of Cultural Property 1970, Sixteenth session, Paris, 14, November, 1970, [Article 03/ Article 6].

[8] Customs Ordinance, [1990] Colombo: Government Press.

[9] De Silva, P. H. D. M. [1996]. Basic Principles of Museums. Colombo: Sri Lanka National Library.

[10] Dharmasiri, M. C. Tourist Guide. [Personal Communication, 2017]. 45yers.

[11] Gunawardhana, Prishantha. [2005]. Archaeological Heritage, Structure, Concepts and Management. Ja-Ela: Samanthi book publishers.

[12] Husen, K. Tourist Guide. [Personal Communication, 2017]. 38yers.

[13] ICOMOS, [1980] Charter for Protection \& Management of Archaeological Heritage.

[14] Liyanage, Sameera. [2003]. History of Archaeology [From begging to 192]. Ganemulla. Author Publications.

[15] Rathnapala, E. M. [1999]. Sri Lanka and Tourists. Diulapitiya: Saraswathi Publications.

[16] Recommendation concerning the International Exchange of Cultural Property. 26, November, 1976.

[17] Recommendation for the Protection of Movable Cultural Property, Twenteeth Session, Paris, 28, November 1978.

[18] Second Protocol to the Hague Convention of 1954 for the Protection of Cultural Property in the Event of Armed Conflict 1999, Hague, 26, May 1999.

[19] Shyaman, C. Antique Shop Owener. [Personal Communication, 2017]. 28yers.

[20] Sugathadasa, C. Antique Shop Owener. [Personal Communication, 2017]. 81yers.

[21] UNESCO. [1983] National Legal Control of Traffic in Cultural Properties, Paris. 